\title{
Measuring the relationship between spatial configuration, diversity and user behavior: A Post Occupancy Evaluation study in Istanbul's peripheral districts
}

\author{
Ayse Ozbil Torun ${ }^{\mathrm{a} * \mathbb{D}}$ \\ Demet Yesiltepe $^{\mathrm{b}}(\mathbb{D}$ \\ Sertaç Erten ${ }^{c}$ (D) \\ Ozlem Ozerd ${ }^{\mathrm{d}}$ \\ Tugce Gurleyen ${ }^{\mathrm{e}}$ \\ Ezgi Zumbuloglu ${ }^{\mathrm{f}}$ (D)
}

\begin{abstract}
Post Occupancy Evaluation (POE) is a robust tool to systematically evaluate the effects of design decisions on spatial performance and to identify the relationship between the space and its users. Although there is a growing body of POE research on complex buildings, such as hospitals and education spaces, studies on the POE evaluation of public open spaces are limited. More importantly, few studies have investigated public squares designed at the periphery and how they are used.

This study aims to identify the extent to which spatial configuration of public squares is related to users' behavior (i.e., modes/distances of access, level of satisfaction). For this purpose, we focused on four peripheral urban squares located in Istanbul, Turkey. The methodology applied in the study includes a synthesis of three types of expertise: 1) behavioral mapping of urban squares (through the analysis of patterns of use based on direct observation), 2) cognitive evaluation of spaces based on perceived factors (through user questionnaires), and 3) quantifying urban public spaces objectively (through the methodology of space syntax and urban morphology).

The results identify associations between objective characteristics of public spaces designed at the peripheral districts, patterns of use and users' perception of these areas, to a certain extent. For example, the variety and intensity of activities within the square as well as the length of occupancy are highest for Avcllar square, which is most integrated within its urban surroundings with reduced average block size. An important finding is the association between the average street connectivity levels of these squares with their pedestrian catchment areas. In other words, the more integrated a public urban space is with its surroundings ( $800 \mathrm{mt}$ buffers), its users will access this space on foot from a larger distance. Based on these findings, spatial configuration as measured by space syntax measures appears to be an explanatory measure assessing the potentiality of public open spaces for bringing users together, hence, creating a lively, well-used space. However, the results also point to some disagreements between the perceived (users' evaluations) and objective (syntactic analysis) measurements, which indicate that both types of measurements are needed in POE research of public spaces.
\end{abstract}




\section{Introduction}

Public spaces are platforms where people can come together or involve in different social activities individually and/or with others. In addition to the personal benefits they provide to the citizens, such as relaxation, transit and circulation, they also enable socially important random encounters and purposeful gatherings (Carr, Francis, Rivlin, \& Stone, 1992; Cybriwsky, 1999; Madanipour, 2003). Good public spaces should offer opportunities for spontaneous activities (Francis, 2010) and different events (Lynch, 1981). Montgomery (1998) stated that places feel lively if they are used by people at different times of the day or if they host different cultural events and celebrations, creating opportunities for informal/casual meetings. Studies also highlighted that the main criteria for a successful space is the use of that space (Whyte, 1980) and if the space is not used by people, then it is not a successful one (Marcus \& Francis, 1998). Similarly, Whyte (1980) and Gehl (1987) highlighted that if a space is used by people, this attracts other people and thus improves the performance of that space. As part of public spaces, urban squares can also be considered as spaces where ceremonial, religion based, social or economic events occur. Since urban squares are generally the focal spaces within cities and can provide their users opportunities of multiple activities, they can be preferred by a relatively higher number of users. Hence, it is quite important to understand different patterns of use and the intensity of uses/density of users within an urban square. Thus, it is important from a design point of view to identify the preferred areas of activities in urban squares, users' needs and perceptions as well as their behavioral patterns.

\subsection{Post Occupancy Evaluation (POE)}

Post Occupancy Evaluation (POE) is a robust tool to systematically evaluate the effects of design decisions on spatial performance and to identify the relationship between the space and its users. Previous research on POE of public spaces have employed observation and/or behavioral mapping techniques to analyze the occupancy of urban squares (Acar et al., 2020; Bin Roslan, Bin Noor Azman, \& Zakariya, 2014; Goličnik, 2005; Goličnik \& Thompson, 2010; Marušić, 2011). Direct observations help us to identify when and how people use these public open spaces whereas behavioral mapping helps us to understand different types of activities users are involved in. Studies using behavioral observations have focused on active and passive activities (Carmona, 2010), such as walking, cycling, standing or sitting, separately. On the other hand, user interviews or surveys were also used in POE literature to understand users' perceptions and their satisfaction levels (Bin Roslan et al., 2014; Fard, 2014). Roslan et al. (2014), for example, asked participants to describe what the urban square means for them. Fard et al. (2014) asked the level of satisfaction by focusing on different criteria such as accessibility, pedestrian safety, lighting or cleanness.

\subsection{Environment and Behavior}

Researchers from different disciplines have been studying to understand how the built environment shapes human behavior. An important part of the studies in this field, defined as environmental-behavioral sciences, is focused on urban open spaces (i.e., streets, squares, green areas). The common argument of this body of work is that in cities where open living spaces are limited, intra-community communication is weakened and individual relations are ignored (Tonkiss, 2005). Therefore, the relationship between social structure and space is mutual (Lefebvre, 1991). In his "Image of the City" (1960), Kevin Lynch, who is considered as one of the leading researchers in the field of environment-behavior, developed a model for the methods used in this field through his observations and interviews aimed at evaluating the perceptions of the citizens about their physical environment. Another important study dealing with the interaction between the built environment and user behavior is "The Social Life of Small Urban Spaces" produced by William Wythe (1980). A significant finding of this comprehensive study, which relies on direct observations and behavioral mapping of urban public spaces, is that the most significant factor in attracting 
people to a space is the presence of other people and that the relationship of the square with the street is the most critical design factor. Applying Whyte's work to different public space typologies, Clare Cooper Marcus and Carolyn Francis showed that the success of a public open space is determined by the intensity of its use while the frequency of its use is directly related to the location of the space within the urban environment (Marcus \& Francis, 1998).

\subsection{Space Syntax: the configurative analysis of urban space}

Space syntax, a set of tools and techniques to understand the relationship between societies and spaces, is a promising approach for measuring the interaction between built spaces and users' behaviors (Hillier \& Hanson, 1984). The main assumption of the method is that any spatial organization has the potential of bringing people together or separating them from each other. In order to test this assumption, various configurational analyses are conducted. As used here, the terms "configurational analysis" refer to any kind of spatial analysis which characterizes the relation of each elementary spatial unit, here the road segment, to all others. The primary goal of these analyses is to measure the potential of spaces in bringing people together depending on the movement within the physical space. However, the distinction between meeting with others in a planned manner or randomly is important, because while the first is independent of the configuration of the space, the latter is the outcome of the spatial configuration (Peponis, 2001). Increasing the possibilities of people to come together randomly through the organization of spaces is important in order to create sustainable, safe and healthy cities by creating active spaces through design.

Studies conducted within the scope of this approach have revealed that there is a statistical relationship between the accessibility (movement areas) and the observed usage and movement patterns (where people are in the space) (Bendjedidi, Bada, \& Meziani, 2019; Garau, Annunziata, \& Yamu, 2020; Hillier, 1996; Hillier \& lida, 2005; Monokrousou \& Giannopoulou, 2016). Studies investigating the impact of urban street networks on the accessibility of public open spaces highlight two aspects of urban fabric: metric accessibility (total route length) and directional accessibility (total number of changes of direction along the route). Metric accessibility measures the distance between origin and destination points. The connection density of an urban network increases accessibility in two ways. First, it reduces walking distances by creating short routes between any pair of origin-destination. Secondly, as street length in an area increases, the width of frontages, and thus the number of attractors, within walking distance also increase. The dense urban grid (relatively small block sizes and high density network) creates interfaces of varying densities between streets and premises, promoting pedestrian travel to maintain daily activities (Frank, Schmid, Sallis, Chapman, \& Saelens, 2005; Kerr, Frank, Sallis, \& Chapman, 2007; Lee \& Moudon, 2006; Reilly \& Landis, 2002). Directional accessibility measures the directness of the route. Empirical studies on spatial perception have revealed that people prefer routes with reduced number of changes when navigating an urban area (Hillier \& lida, 2005; Jansen-Osmann \& Wiedenbauer, 2004). This is in line with findings of studies in the fields of cognitive neurology and environmental psychology, which have shown that direction changes limit the ability to navigate because they require cognitive effort (Crowe, Averbeck, Chafee, Anderson, \& Georgopoulos, 2000).

\subsection{Diversity}

Diversity is directly connected to the concept of "spatial diversity", here defined as the presence of heterogeneous land-uses, which can harbor, support, and develop differences in human activity (Marcus \& Colding, 2014). Urban form indicator of diversity is short blocks, mixed-use (Jacobs, 1993) and functional variety (Dovey \& Polakit, 2009; Ramírez-Lovering, 2008). Mixed and compatible land-uses would bring a variety of forms, functions, and activities to the urban streets, which would consequently play a significant role in enhancing urban resilience quality of the area. 


\subsection{Research Focus}

Although there is a growing body of POE research on buildings, such as hospitals (Marcus \& Francis, 1998; Preiser, 1994), residences (Becker, 1977; Karagenç, 2001) and education spaces (Gürcan, 2002; Preiser, 2001; Rabinowitz, 1975; Sanoff, 1994), studies on the POE of public open spaces are quite limited (Churchman \& Ginosar, 1999; Kılıç, 2001; Korkmaz, 2001; Sherman, Varni, Ulrich, \& Malcarne, 2005; Whitehouse et al., 2001). More importantly, the majority of such studies have focused on the evaluation of public spaces located within city centers (Akad \& Çubukçu, 2006; Kılıç, 2001; Malkoc \& Ozkan, 2010). Few studies have investigated public squares designed at the periphery and how they are used (Çakılcıoğlu, Reyhan, \& Kurt, 2010; Hepcan, Kaplan, Küçükerbaş, \& Özkan, 2001). This is an important gap in the literature, because the physical and functional development of today's metropolises is based on their growth towards the urban periphery (Çalışkan, 2005). In this growth process, it is important to determine user expectations as well as the perceptual, aesthetic and functional characteristics of urban squares located in the periphery in increasing the spatial performance of these spaces to be designed in the future. Another shortcoming of studies on post-occupancy evaluation of public urban spaces is their tendency to investigate urban spaces as singular entities within their physical boundaries, isolated from their urban context. However, spatial performance is actually associated with the character of an entire area -a neighborhood or a district. Hence, behavioral patterns prevalent in an area cannot be described by analyzing the immediate neighborhood isolated from its global surroundings.

This study addresses the above-described shortcomings by focusing on peripheral urban squares and analyzing simultaneously objective (existing physical data/field observations) and perceived (questionnaires) environmental attributes to identify their relative impact on the use of these spaces. The objective analysis of the selected urban squares considers these spaces within their global urban context, using detailed, micro-level units of analysis. The main aim of this paper is to identify the extent to which spatial configuration of public squares located at the periphery is related to users' behavior (i.e., modes/distances of access, level of satisfaction).

\section{Method}

This study includes a synthesis of three types of expertise: 1) behavioral mapping of areas (through the analysis of patterns of use based on direct observation), 2) cognitive evaluation of spaces based on perceived factors (through user questionnaires), and 3) quantifying urban public spaces objectively (through the methodology of space syntax and urban morphology).

\subsection{Study Areas}

This study focuses on four urban squares located in Istanbul's peripheral areas, which function as sub-centers for their surroundings. These areas -Küçükçekmece, Büyükçekmece, Beylikdüzü and Avclar- are chosen since they are located in districts that have grown towards the outskirts between 1980 and 2000 parallel to E-5 highway, which functions as the major arterial of the city. After 2000, these districts have retained their peripheral characteristics yet at the same time served as sub-centers for the surrounding regions. All four squares are located nearby the E- 5 highway to be easily accessible by pedestrians and by public transport. Küçükçekmece Square is the center of the region that acts as a link between the metrobus stop and the train station and that represents the center of the old district. Avcilar Square and its street arrangement offer a linear open space configuration within a traditional street character. Beylikdüzü Square is planned as a wide overpass that serves directly to the metrobus station and is a referenceless square where passenger movements are dominant. Büyükçekmece Square, on the other hand, is a public open space arrangement, which does not have a metrobus connection yet, but due to the transportation investments made, these connections will be provided in the near future, so it has the potential to 
become a pedestrian attraction center. Figure 1 shows the four study areas on the map of Istanbul and Figure 2 demonstrates the squares within their immediate urban context.

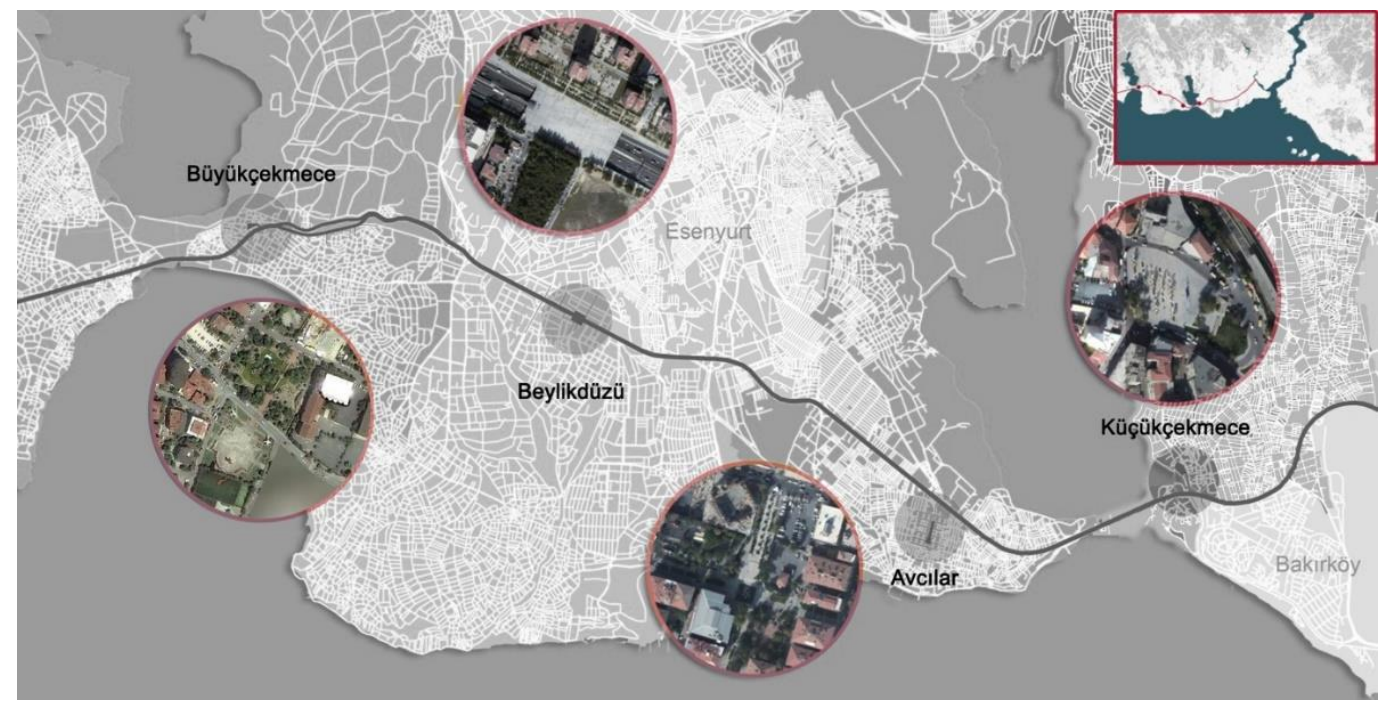

Figure 1 Location of four squares.

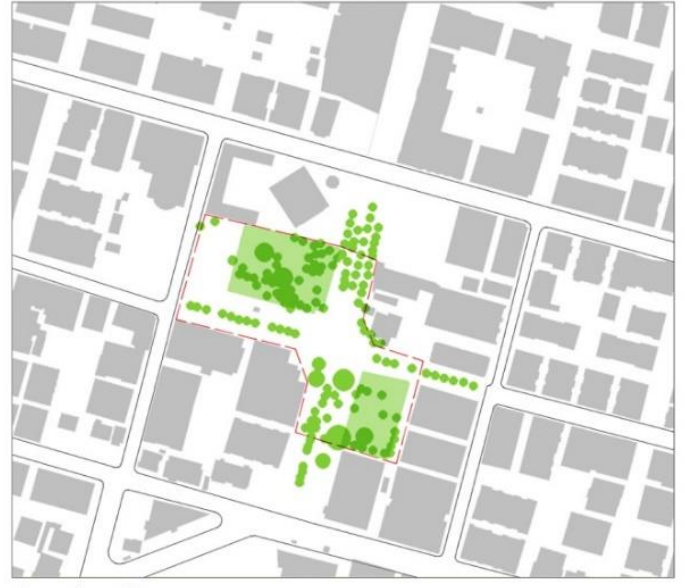

Avc1lar Square

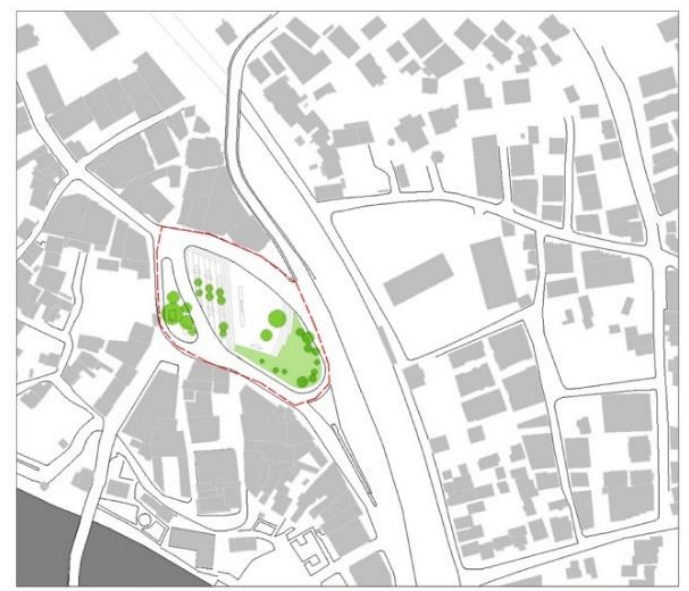

Küçükçekmece Square

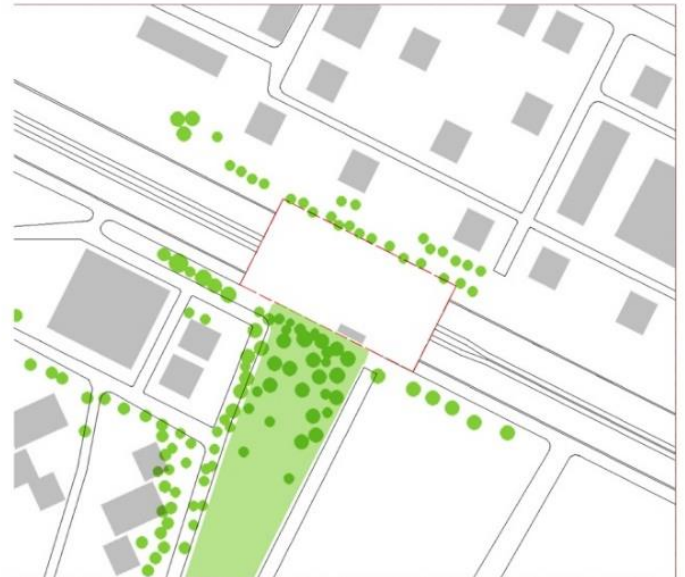

Beylikdüzü Square

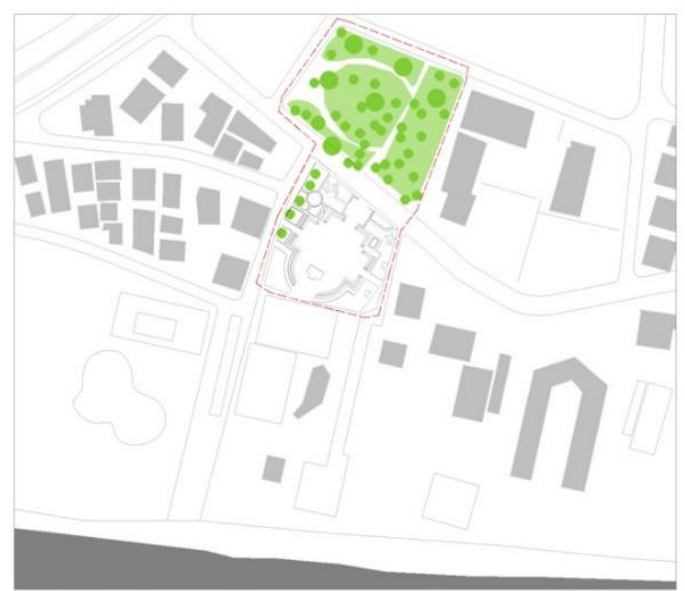

Büyükçekmece Square

Figure 2 The squares within their immediate urban context. 


\subsection{Observation and Behavioral Mapping}

User behavior was measured through direct observations within 10-minute intervals using the methodology developed by Goličnik Marušić and Marušić (2012) and similar to previous studies (Hermida, Neira, Cabrera-Jara, \& Osorio, 2017; Schwebel et al., 2018). Spatial behavior mapping was conducted for both passive and active occupancies within the squares on multiple days (weekend and weekday), repeated over 5 time intervals (from 8 am to $8 \mathrm{pm}$ ) during one day. Observations and behavioral mapping were conducted for one year to record seasonal differences. Figure 3 displays the set of activities along with their symbols recorded in Küçükçekmece square for one observation session. Activities are grouped under two categories, primary and secondary. Primary activities include walking, sitting, lying down, and standing. Secondary activities include sleeping, conversing, smoking and watching around. In line with previous studies (Long, Rain, \& Ratcliffe, 2001), the results of observations and mapping were then translated into Geographic Information Systems (GIS) to quantitatively analyze the patterns of use, similar to previous studies.

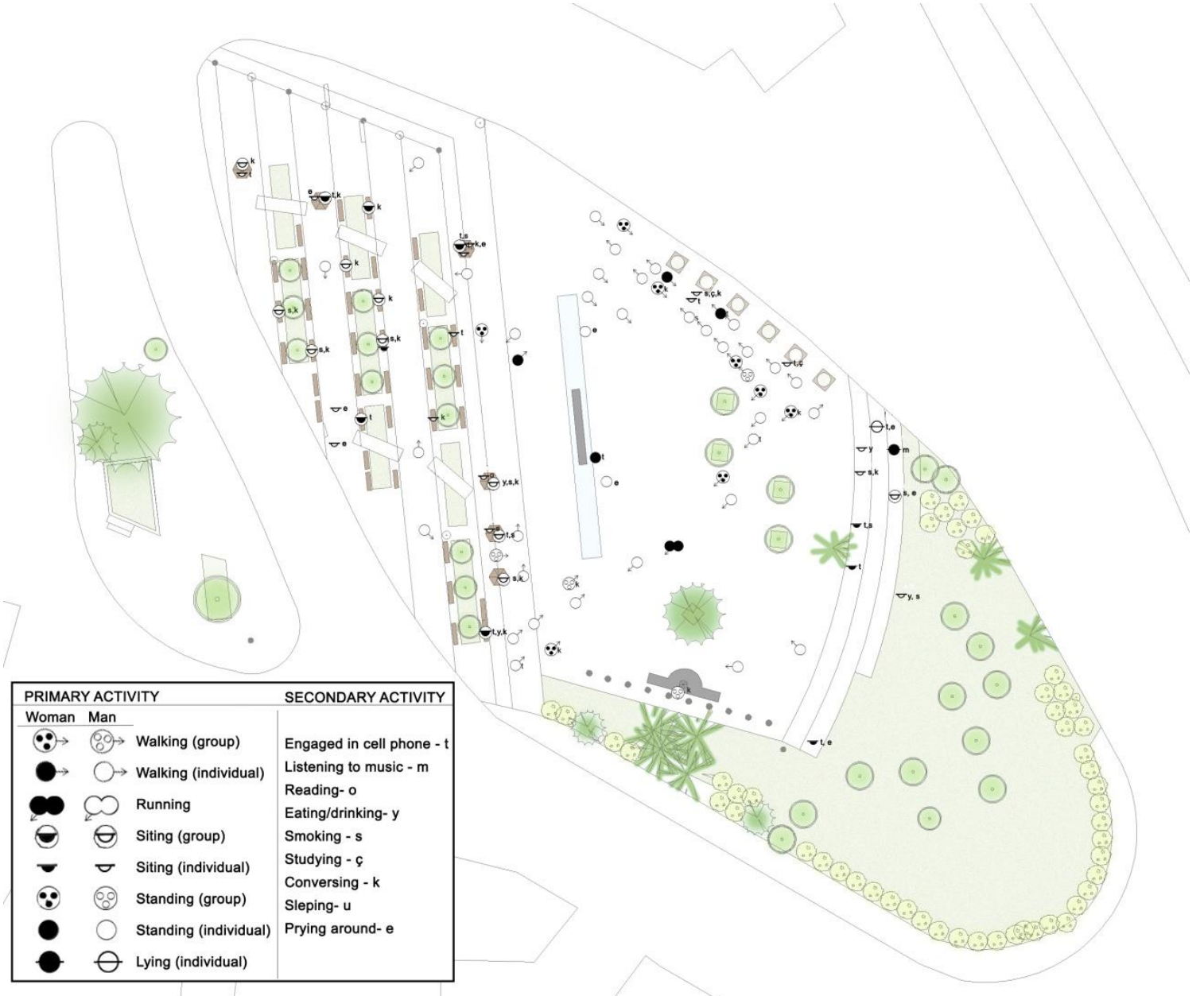

Figure 3 Primary and secondary activities, including their attached symbols, specifying male and female users, used for recording activities in Küçükçekmece square within one observation session.

\subsection{User Questionnaires}

A questionnaire was designed in Turkish to explore users' perceptions about the squares. Data collection was undertaken from September 2015 to September 2016. To be consistent with the observations and behavior maps, face-to-face questionnaires were conducted with randomly selected users within the 4 squares on weekdays and weekends in the mornings, afternoons and evenings. During the survey, participants were asked to answer (1) demographic questions such as 
education and gender, (2) the purpose and the frequency of using the square, (3) access mode and if accessed on foot, the distance walked, (4) questions about their level of satisfaction with the square in terms of safety, accessibility, walkability and design/maintenance. Of the 1,339 users who participated in the questionnaires, 558 were male (42\%) and 781 were female (58\%). A total of 337, 341, 329, and 332 users participated in the questionnaire in Küçükçekmece, Büyükçekmece, Beylikdüzü and Avcılar squares respectively.

The study protocol was approved by Ethics Commission, Özyeğin University (Ethics ID 2015/01) and relevant permissions were granted by the Municipality of Istanbul (ID 30872936-02-622.01) and the Governship of İstanbul (ID 47909374-16772.(31727).2015/5190).

\subsection{Spatial Configuration and Diversity}

As 800 meters, a 10-minute walking distance is considered as the walking threshold that people are willing to walk between origins and destinations within the city (El-Geneidy, Grimsrud, Wasfi, Tétreault, \& Surprenant-Legault, 2014; Riazi \& Faulkner, 2018), urban form within 800meter radius buffers around the urban squares is studied in this paper. The term 'square-areas' is used to indicate these buffers from here on. Urban form of square-areas is measured through evaluating spatial configuration of the surrounding street network and the land-use compositions within these areas.

The spatial configuration of street network within the study areas is evaluated using two basic descriptors of spatial structure of street networks applied in Space Syntax literature. Connectivity measures the number of spaces (streets segments) intersecting each space within the system. Segment Angular Integration measures how accessible each space is from all the others within the radius using the least angle measure of distance. Integration (radius $\mathrm{n}$ ) and connectivity for 800meter radii were calculated for each square using Depthmap X (Turner, 2001; Varoudis, 2014). Figure 4 demonstrates the street network configuration of two square-areas using these two measures.

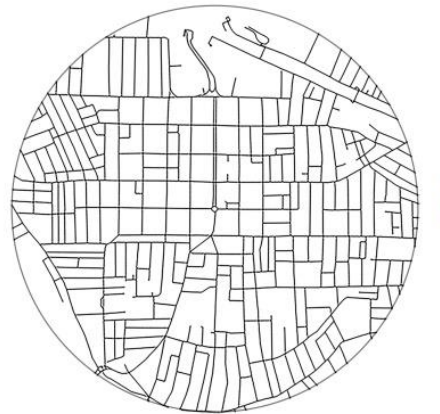

Avcilar Network

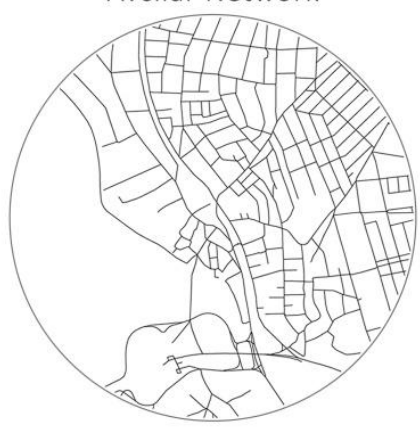

Küçükçekmece Network

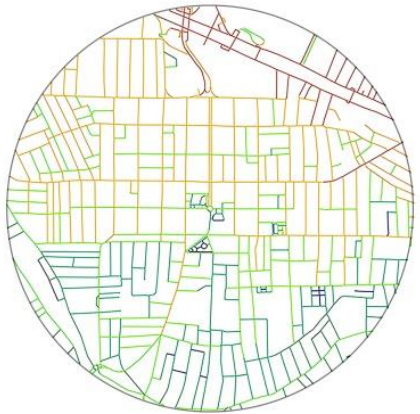

Integration

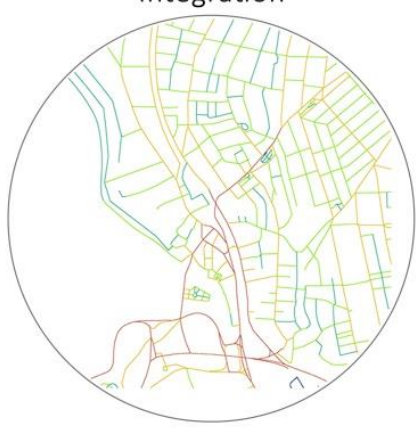

Integration

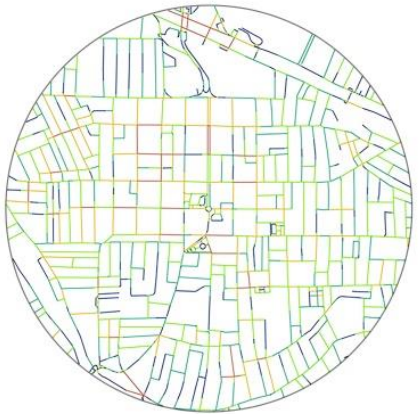

Connectivity

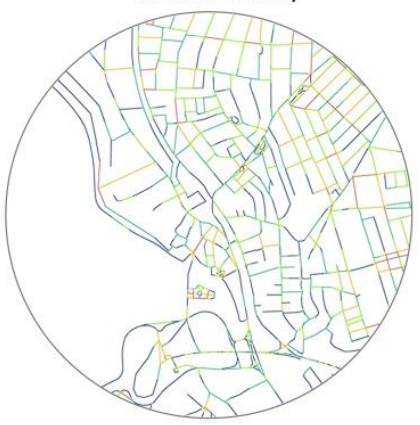

Connectivity

Figure 4 Avcılar and Küçükçekmece square-areas (800 meter circular buffer) represented with street network centerlines, Integration (n), and Connectivity measures. 
In this study diversity is measured through the analysis of the ground-floor land-use patterns around the urban squares. Density of total land-uses as well as residential, non-residential (office + retail + commercial) and recreational land-uses are calculated separately within square-areas. Figure 5 shows the composition of land-uses within these areas. The study focuses on ground floor land-uses only since non-residential uses located on the ground floor act as 'movement attractors'.

Page| 91
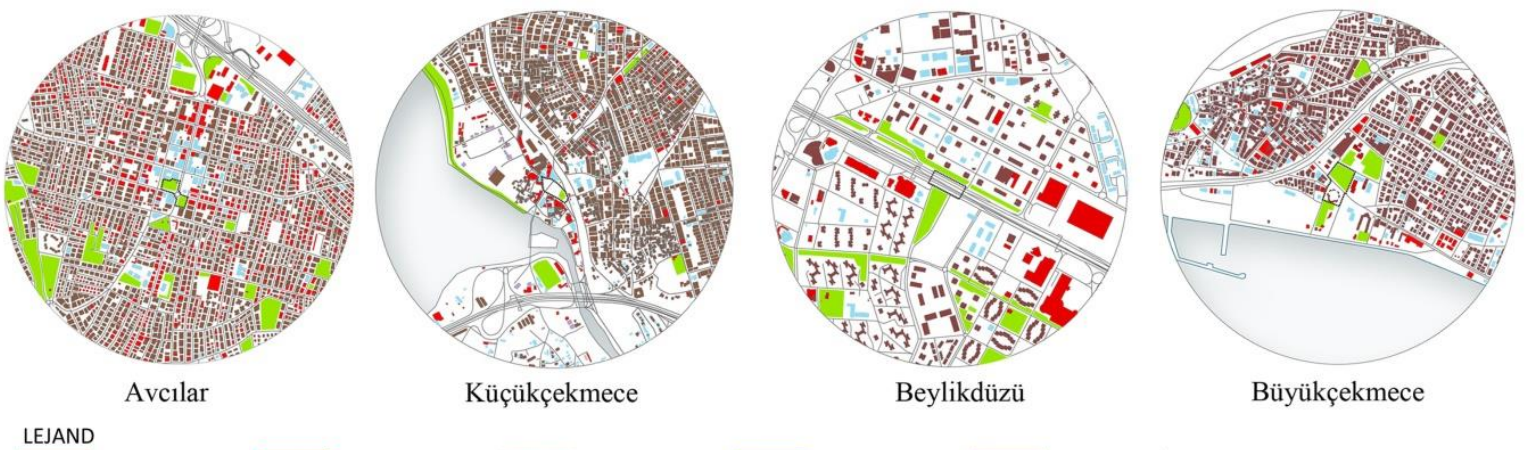

Residential Commercial Institutions

Green Areas

Industrial / Storage

Figure 5 Land-use compositions within the square-areas ( 800 meter circular buffer).

\section{Analysis and results}

\subsection{Observations and Behavioral Mapping}

Figure 6 displays the set of activities along with their symbols recorded in all four squares for a typical observation session. Küçükçekmece square is mostly used for sitting and conversing by the elderly population. Hence, there is a limited variety of activities. The primary activities mostly include the passive occupancy of sitting, while the secondary activities consist mainly of conversing. Although the perimeter of the square is used as a transition route between origin and destination, the square itself serves as a space for passive usage (sitting on benches within the square). Büyükçekmece square, on the other hand, is an under-used open urban public space. This square has the least intensity in usage among the four areas and the variety of activities is limited within the square. The space is used mostly as a transition zone, where uses such as sitting or lying down are less likely to occur. The recreational park attached to the transition zone is mostly used for longstay passive activities, including sitting, resting, and conversing. Similarly, Beylikdüzü square is predominantly used as a transition space that is in conformity with the frequency of use and length of occupancy. There is a limited variety of passive activities, such as sitting in trellises, since this square offers few street elements (i.e., benches, kiosks) and limited variety in its functional spaces (i.e., playground) and is just located above a bus rapid transit route. Limited long-term active uses mostly include roller-skating and skateboarding. Behavior mapping shows that Avcllar square has the highest intensity of usage both in short-and long-term stay. While the center of the square is used as a transition zone, the recreational park and the cafeteria area within the square are predominantly used for long-term secondary activities, including a wide range of active uses, such as children at play, and passive activities, such as sitting and reading newspaper, eating/drinking, conversing and photographing. Behavioral patterns show that activities are well distributed within the square. 

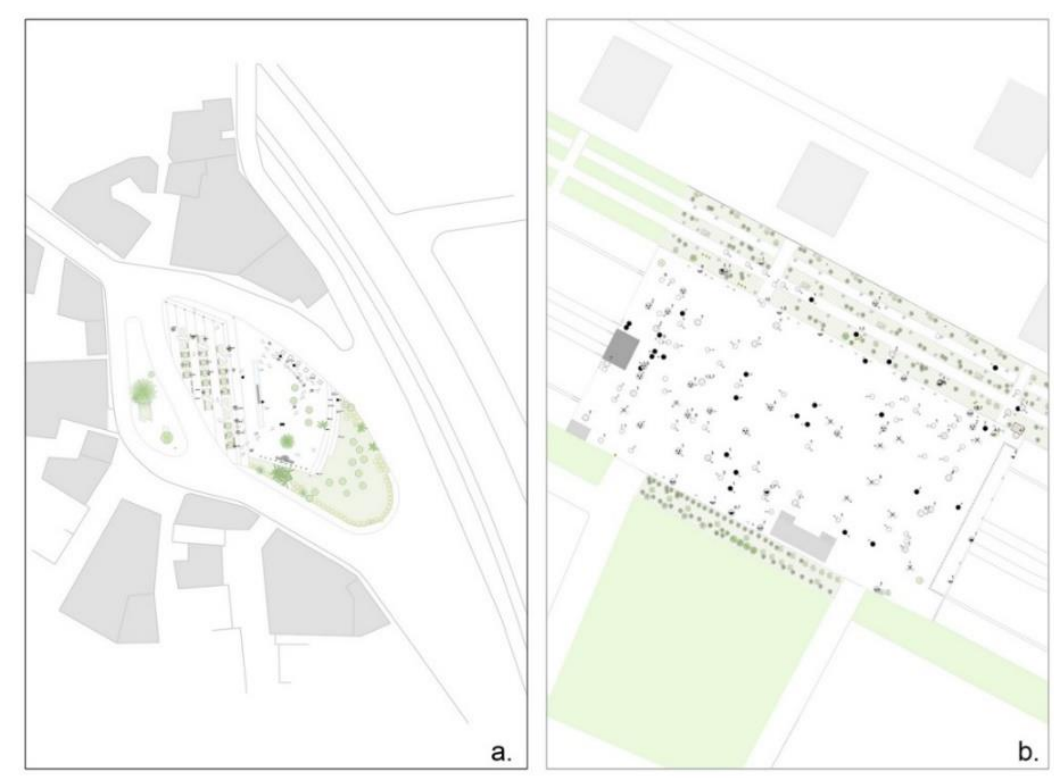

Page | 92
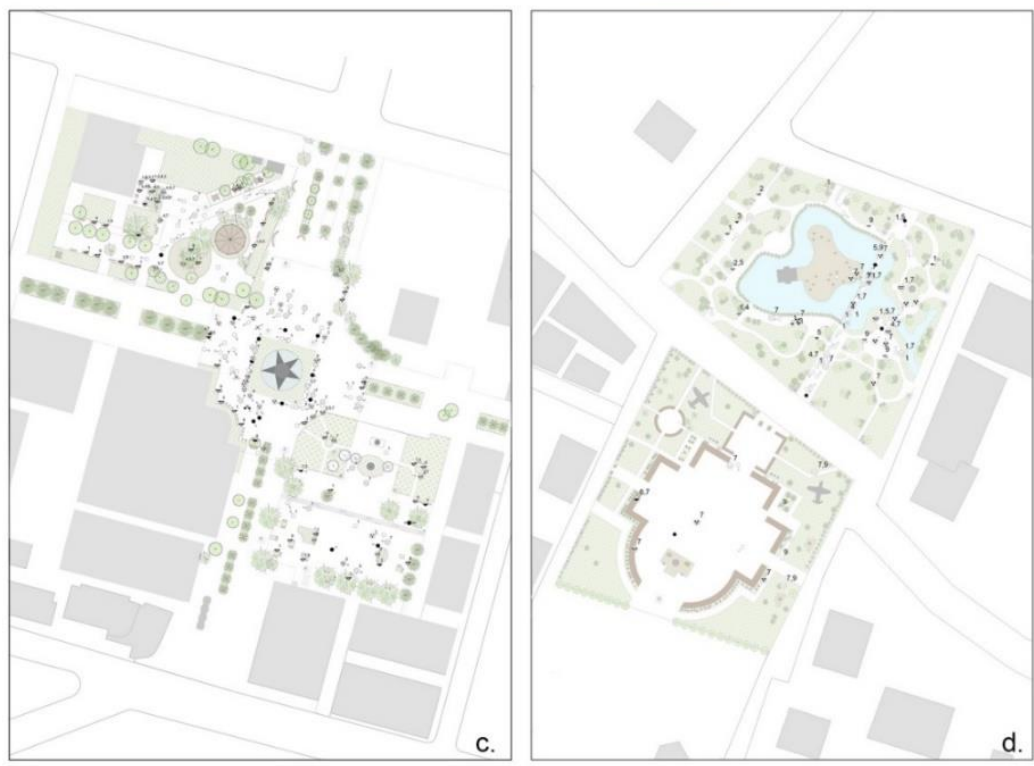

PRIMARY ACTIVITY

SECONDARY ACTIVITY

个

(6) $\rightarrow$ Walking (group)

$\rightarrow$ Walking (individual)

๑ Running

$\ominus \ominus$ siting (group)

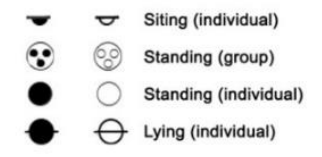

Engaged in cell phone $-t \quad$ Studying $-\varepsilon$

Listening to music $-\mathrm{m} \quad$ Conversing $-\mathrm{k}$

Reading- o

Conversing $-k$
Sleping- $u$

Eating/drinking-

Smoking - s

b.

Figure 6 Behavioral mapping of the four squares (a. Küçükçekmece, b. Beylikdüzü, c. Avcılar and d.Büyükçekmece squares) during a typical observation session.

\subsection{Survey Results}

Table 1 lists the findings summarizing the percentages obtained from the user questionnaires in each square. Participants' age and education levels do not vary significantly between squares. Küçükçekmece square has the highest percentage of elderly users (aged 64+). While the level of education (with a college degree and/or above) among users is the highest in Beylikdüzü (31\%), it is the lowest for Büyükçekmece (9\%).

According to these results, the percentage of access to squares via bus rapid transit (Metrobus) is highest for Beylikdüzü Square, which is located directly on a bus rapid transit stop/route. Yet, 
auto access to this square is the highest as well. The rate of people walking to the square is highest for Küçükçekmece Square, while this rate is lowest for Büyükçekmece and Avcılar Squares.

The walking catchment area, the distance people are willing to walk to the squares, is highest for Avcilar (more than half of the participants walk between 800 and 1600 meters (55\%), and approximately $10 \%$ walk more than 1600 meters). Contrarily, the results indicate that participants perceive the surroundings of this square as the least walkable among the four square-areas $(21 \%$ strongly disagree and/or disagree) and the percentage of users agreeing/strongly agreeing that this square is easily accessible is the lowest (64\%). While the frequency of daily use is highest for Büyükçekmece (35\%) and Küçükçekmece (38\%), Avcılar square is used several times a day by more users as compared to other squares. The length of occupancy is the highest for Avcllar square (almost $1 / 3$ of participants occupy the square between 2 -to-4 hours, and more than $10 \%$ stay more than 4 hours). On the contrary, Küçükçekmece and Beylikdüzü appear to have the lowest length of occupancy, with almost $40 \%$ and $30 \%$ of users spending less than an hour respectively and almost half of them spending only 1 to 2 hours. In addition, users' rate of preference of squares as places for socio-cultural activities and socializing is highest for Avcılar. Surprisingly, accessibility to landuses within the square-area are perceived to be the lowest for Avcilar while the number of users perceiving to have access to many shops and destinations within 5-to-10 minutes walking distance to the square is highest for Küçükçekmece and Büyükçekmece.

Table 1 Findings indicating percentages obtained from the user questionnaires in each square.

\begin{tabular}{|c|c|c|c|c|c|}
\hline Statements & Categories & Küçükçekmece & Büyükçekmece & Beylikdüzü & Avcilar \\
\hline \multirow{5}{*}{$\begin{array}{l}\text { Walking } \\
\text { distance }\end{array}$} & $>400 m(0-5 \mathrm{~min})$ & 32.93 & 31.30 & 31.85 & 21.82 \\
\hline & 401-800mt (5-10min) & 28.14 & 40.00 & 25.93 & 23.64 \\
\hline & $801-1200 \mathrm{mt}$ (10-15min) & 27.54 & 18.26 & 25.19 & 27.88 \\
\hline & $1201-1600 \mathrm{mt}(15-30 \mathrm{~min})$ & 9.58 & 6.09 & 15.56 & 17.58 \\
\hline & $>1600 m t(30+\min )$ & 1.80 & 4.35 & 1.48 & 9.09 \\
\hline \multirow[t]{4}{*}{ Access mode } & metrobus & 8.04 & 3.80 & 29.48 & 27.38 \\
\hline & bus/shared taxi & 36.90 & 54.09 & 17.63 & 29.11 \\
\hline & automobile/taxi & 5.65 & 8.19 & 11.85 & 10.37 \\
\hline & walking & 49.40 & 33.92 & 41.03 & 33.14 \\
\hline \multirow{8}{*}{$\begin{array}{l}\text { Frequency of } \\
\text { use }\end{array}$} & several times/day & 0.59 & 0.00 & 1.83 & 6.27 \\
\hline & everyday & 37.98 & 34.60 & 24.39 & 23.58 \\
\hline & 2- 3 times/week & 17.51 & 26.98 & 32.93 & 29.55 \\
\hline & once/ week & 16.02 & 18.48 & 17.07 & 12.24 \\
\hline & once/ 10 days & 4.15 & 3.52 & 7.32 & 3.88 \\
\hline & once/month & 13.95 & 8.21 & 13.72 & 18.51 \\
\hline & 1 or 2 times/year & 8.01 & 7.04 & 1.83 & 3.88 \\
\hline & less than once /year & 1.78 & 1.17 & 0.91 & 2.09 \\
\hline \multirow{5}{*}{$\begin{array}{l}\text { Length of } \\
\text { occupancy }\end{array}$} & $<1$ hour & 40.65 & 19.35 & 30.40 & 7.58 \\
\hline & $1-2$ hours & 44.21 & 55.13 & 50.46 & 52.73 \\
\hline & $2-4$ hours & 12.76 & 20.23 & 12.46 & 27.88 \\
\hline & 4-6 hours & 1.48 & 4.69 & 3.65 & 4.85 \\
\hline & $>6$ hours & 0.89 & 0.59 & 3.04 & 6.97 \\
\hline \multirow[t]{2}{*}{ Aim of use } & Socio-cultural activities & 1.53 & 2.92 & 4.87 & 5.88 \\
\hline & $\begin{array}{l}\text { Socializing with other } \\
\text { people }\end{array}$ & 2.23 & 1.65 & 2.92 & 7.47 \\
\hline \multirow{3}{*}{$\begin{array}{l}\text { This square is } \\
\text { accessible }\end{array}$} & SA & 33.43 & 39.59 & 38.41 & 31.61 \\
\hline & A & 38.21 & 37.83 & 43.60 & 33.13 \\
\hline & $\mathrm{D}$ & 11.04 & 4.69 & 3.96 & 10.94 \\
\hline
\end{tabular}




\begin{tabular}{|c|c|c|c|c|c|}
\hline & SD & 3.88 & 2.35 & 0.91 & 3.65 \\
\hline \multirow{4}{*}{$\begin{array}{l}\text { It is easy to } \\
\text { walk around } \\
\text { this square }\end{array}$} & SA & 50.75 & 60.83 & 27.22 & 22.59 \\
\hline & $A$ & 19.40 & 21.36 & 48.62 & 26.81 \\
\hline & $D$ & 8.96 & 6.53 & 5.81 & 13.55 \\
\hline & SD & 8.66 & 3.26 & 0.92 & 7.23 \\
\hline \multirow{4}{*}{$\begin{array}{l}\text { It is easy to } \\
\text { access to the } \\
\text { center from } \\
\text { this square / } \\
\text { its } \\
\text { surroundings }\end{array}$} & SA & 41.74 & 46.15 & 30.89 & 26.75 \\
\hline & $A$ & 31.78 & 32.84 & 51.07 & 26.75 \\
\hline & D & 9.35 & 5.03 & 3.98 & 10.94 \\
\hline & SD & 0.31 & 0.59 & 0.92 & 3.65 \\
\hline \multirow{4}{*}{$\begin{array}{l}\text { The distance } \\
\text { between } \\
\text { intersections } \\
\text { within this } \\
\text { square area is } \\
\text { short }\end{array}$} & SA & 31.93 & 38.81 & 29.23 & 20.73 \\
\hline & $A$ & 43.07 & 43.58 & 54.15 & 35.98 \\
\hline & $D$ & 9.64 & 3.88 & 3.08 & 12.80 \\
\hline & $S D$ & 2.11 & 0.60 & 1.23 & 2.13 \\
\hline \multirow{4}{*}{$\begin{array}{l}\text { There are } \\
\text { many } \\
\text { destinations } \\
\text { within 5- } \\
\text { 10min } \\
\text { walking } \\
\text { distance }\end{array}$} & SA & 17.51 & 20.71 & 29.57 & 31.52 \\
\hline & $A$ & 60.24 & 61.24 & 44.82 & 37.27 \\
\hline & $\mathrm{D}$ & 4.45 & 2.66 & 3.05 & 7.27 \\
\hline & SD & 1.78 & 0.89 & 2.44 & 2.73 \\
\hline \multirow{4}{*}{$\begin{array}{l}\text { There are } \\
\text { many shops } \\
\text { within 5- } \\
\text { 10min } \\
\text { walking } \\
\text { distance }\end{array}$} & SA & 56.51 & 50.58 & 27.66 & 41.46 \\
\hline & $A$ & 30.77 & 34.80 & 51.67 & 28.66 \\
\hline & $D$ & 2.96 & 2.63 & 4.86 & 4.88 \\
\hline & SD & 5.33 & 4.97 & 3.04 & 2.13 \\
\hline \multirow[t]{2}{*}{ Gender } & Female & 53.71 & 55.43 & 63.22 & 61.14 \\
\hline & Male & 46.29 & 44.57 & 36.78 & 38.86 \\
\hline \multirow[t]{2}{*}{ Education } & $<$ college & 87.41 & 91.11 & 68.90 & 87.63 \\
\hline & $>$ college & 12.59 & 8.89 & 31.10 & 12.37 \\
\hline \multirow[t]{3}{*}{ Age } & $18-44$ & 51.46 & 63.78 & 68.69 & 68.20 \\
\hline & $44-64$ & 36.04 & 28.93 & 26.87 & 25.12 \\
\hline & $64+$ & 12.50 & 7.29 & 4.44 & 6.68 \\
\hline
\end{tabular}

SD: strongly disagree, D: disagree, A: agree, SA: strongly agree. For the purpose of this table, Neutral (N) values are not reported here.

In addition, participants reported their level of agreement with a set of statements, using a 5point scale ('strongly disagree', 'disagree', 'neutral', 'agree', and 'strongly agree', coded from 1 to 5 respectively), regarding their perception of the square. Figure 7 shows the average values for the participants' satisfaction levels. This figure demonstrates that the level of satisfaction with the square itself is highest in Beylikdüzü square. Results of the survey highlighted Beylikdüzü square as a cleaner, safer, more spacious, more coherent, more dynamic, more intelligible, more relaxing, more attractive, more different and greener space perceived by its users than the other three squares. While Büyükçekmece and Avcılar squares have similar satisfaction levels, Küçükçekmece square has the lowest satisfaction level in all categories. 


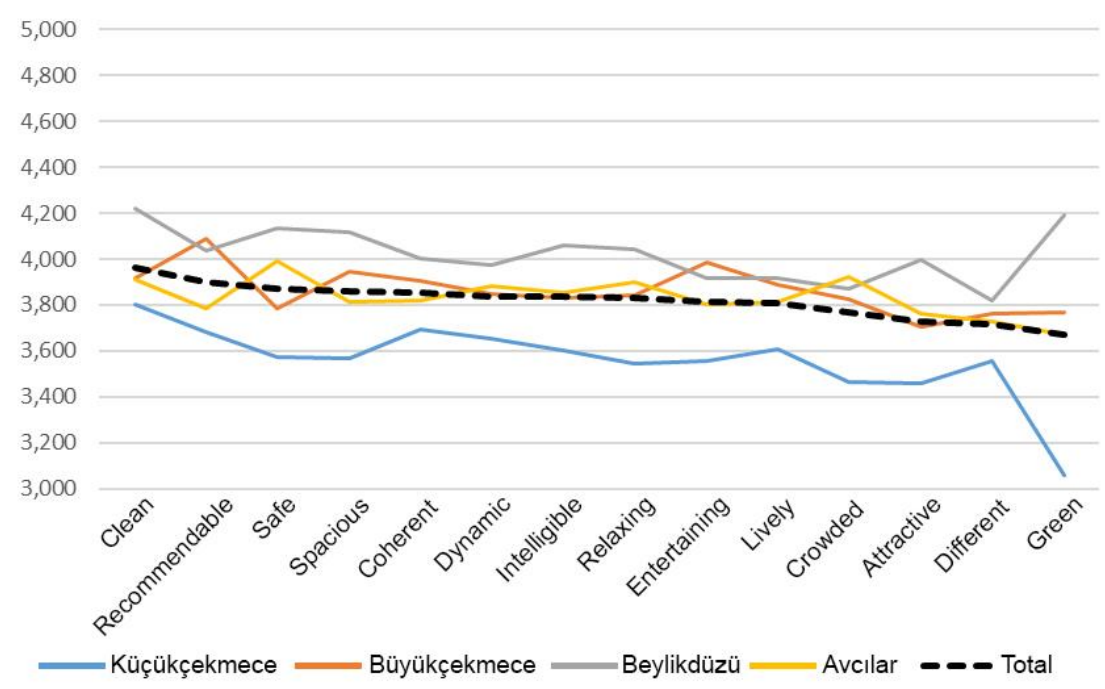

Figure 7 Participants' evaluation based on the survey. Lines show the average of the rates (higher scores show higher satisfaction level).

\subsection{Spatial Configuration and Diversity within Square-Areas}

Table 2 summarizes patterns of spatial configuration and diversity of study areas. Results indicate that Avclar includes the shortest average block size with highest total street length and total number of segments, while Beylikdüzü has the largest average block size with the least amount of street segments within its buffer. Similarly, Avcılar has the highest number of intersections within its buffer whereas Beylikdüzü has the lowest. Küçükçekmece and Büyükçekmece square-areas are comparable in terms of intersection density. In terms of connectivity, Avcılar and Küçükçekmece are the most integrated public spaces within their urban context. Average connectivity values of all square-areas are comparable, with Avcılar having the highest average street connectivity within its buffer.

Table 2 Descriptive statistics summarizing urban form within study areas.

\begin{tabular}{|c|c|c|c|c|}
\hline & Küçükçekmece & Büyükçekmece & Beylikdüzü & Avcilar \\
\hline \multicolumn{5}{|l|}{ Morphology } \\
\hline avg. block size (m) & 62 & 61 & 82 & 57 \\
\hline total street length (m) & 44.035 & 35.049 & 43.282 & 56.286 \\
\hline total \# street segments & 659 & 563 & 456 & 967 \\
\hline total \# of intersections & 260 & 262 & 168 & 394 \\
\hline \multicolumn{5}{|l|}{ Connectivity } \\
\hline avg. Integration (n) & 9,613 & 6,532 & 7,741 & 8,914 \\
\hline avg. Connectivity & 3.12 & 3.3 & 3.15 & 3.34 \\
\hline \multicolumn{5}{|l|}{ Diversity (m2) } \\
\hline total land-use density & 476,974 & 411,491 & 455,033 & 604,3 \\
\hline total residential density & 381,579 & 320,963 & 268,469 & 302,15 \\
\hline total retail density & 38,158 & 32,919 & 59,154 & 151,075 \\
\hline total recreational density & 38,158 & 41,149 & 100,107 & 114,817 \\
\hline Population (persons) & 49,895 & 62,885 & 115,994 & 88,854 \\
\hline
\end{tabular}


When the ground-floor land-use percentages are analyzed (Figure 8), Avcılar appears to include the most diverse land-use distribution, while Küçükçekmece and Büyükçekmece are predominantly residential. Beylikdüzü seems to possess similar densities of ground floor percentages to Avcılar. However, while the latter includes a fine-grained land-use pattern, Beylikdüzü encompasses coarsegrained active ground floor uses (i.e., large shopping malls).

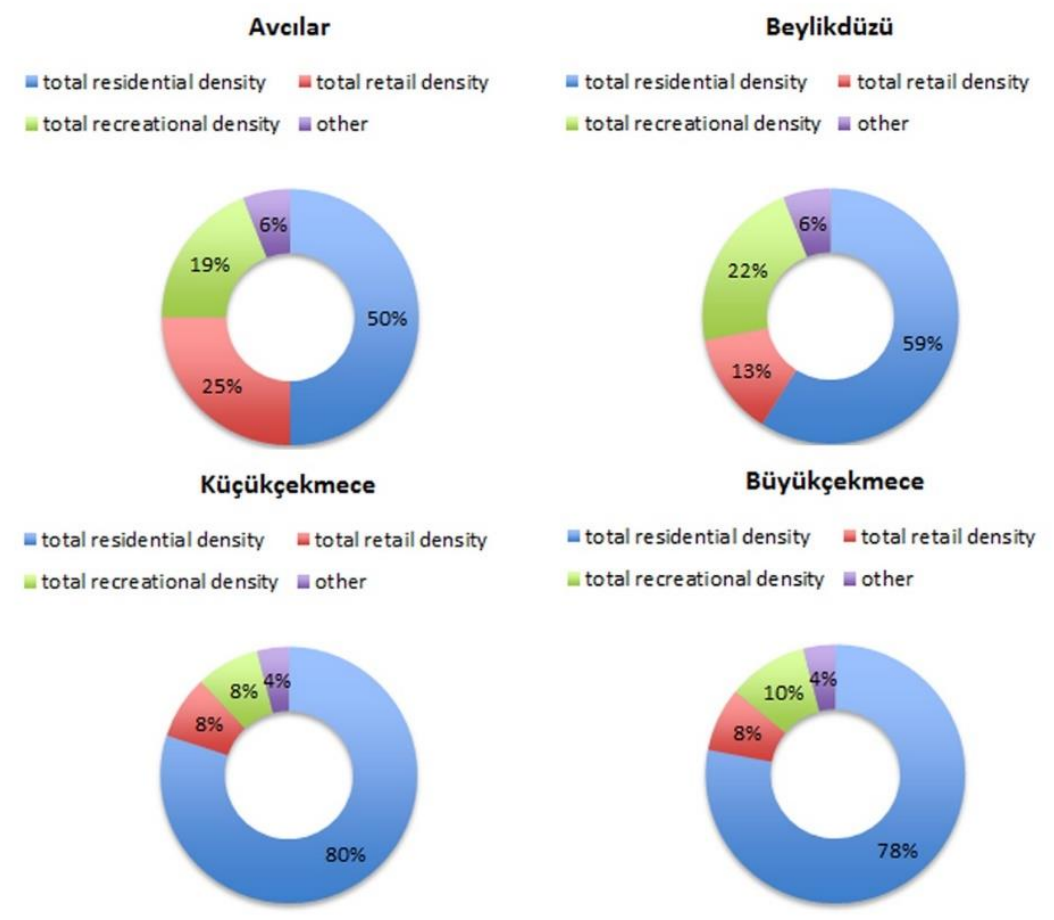

Figure 8 Land-use distributions within 800 meter circular buffers of selected squares.

\section{Discussions}

The results of urban form characteristics of square-areas, users' perceptions, and user behavior within the squares indicate that there is indeed a correlation between these three sets of measurements of open public spaces. For example, the variety of primary and secondary activities within the square as well as the length of occupancy are highest for Avcllar square, which is most integrated within its urban surroundings with reduced average block size. Similarly, Avcllar square, which has the highest number of street segments and total length of street within its $800 \mathrm{mt}$ buffer, has the highest average walking distances among the four selected areas. Users, on the other hand, choose to spend less time in Beylikdüzü square, which has increased average block sizes and reduced Integration within its 800 -meter radius buffer. Thus, it can be claimed that the increased integration of the square with its urban context (a 10 minute walking area or 800 meter radius) stimulates its users to occupy and to use the urban square for their pastime.

The findings of this research can be grouped under three main headings.

\subsection{Significance of Spatial Configuration}

When addressing usage-spatial relationships in open urban public design, spatial configuration of spaces within their urban context becomes important. Based on the analyses conducted within this paper, spatial configuration as measured by space syntax measures appears to be an 
explanatory measure assessing the potentiality of public open spaces for bringing users together, hence, creating a lively, well-used space. The findings of this study indicate that the integration level of a peripheral urban square within its immediate urban context (10 minute walking distance) plays an essential role in supporting the life of the square. Integration provides us the ability of the square to get connected with other parts of the city, which is very important in terms of the intensity and frequency of its occupation. Our findings indicated that the more integrated a public urban space is with its surroundings (800mt buffers), its users will access this space on foot from a larger distance. These findings complement earlier research indicating that streets, which are highly integrated in the street system, attract a lot of movement (Hillier, Penn, Hanson, Grajewski, \& Xu, 1993), but also significantly contribute to usage-spatial relationships.

\subsection{Significance of Diversity}

Diversity, as measured through the variety of land-uses, allows planners/designers to investigate the ability of the built environment to transform into a different land-use model and to sustain the activities of the city. When the distribution of land-uses is analyzed, Avcılar has relatively increased diversity of uses within its 800 meter buffer. This is in conformity with the behavioral patterns of urban space (i.e., increased intensity of use and higher variety of activities). Thus, it may be claimed that urban squares located within urban areas with relatively diverse land-use distributions appear to have increased capacity for creating sociable and dynamic spaces. However, the distribution of land-uses within an urban space should also be considered along with the grain of parcels, because as it is the case with Avcilar square-area, a more fine-grained land division seems to promote a wellused open space which eventually becomes an important social node for the city. In dense but loose-street pattern communities, like Beylikdüzü, urban squares do not function as the main gathering spaces. One reason is that this settlement type represents coarse-grain lots and pointblock isolated building morphology, which damage walkable environments. Therefore, while spatial configuration of the street network layout around the urban squares is the primary planning parameter that shapes the user behavior within these public open spaces (i.e., frequency and intensity of use as well as the walking catchment areas to squares), diversity can be considered as a complementary parameter.

\subsection{Significance of Objective and Perceived Measures of Built Environment}

In POE studies of public open spaces, both objective and perceived urban form measures should be employed. The findings of user questionnaires point to some disagreements between the objectively measured and perceived built environment attributes. For example, even though Avcılar square-area has the highest street connectivity (i.e., highest total number of intersections, smallest average block size, highest Integration and connectivity levels) when measured through objective GIS-based measures, participants within this square perceived the surroundings of this square as the least walkable and less accessible among the four square-areas. Similarly, while Beylikdüzü square-area is less-integrated within its surroundings with the least number of intersections and highest average block size, the level of satisfaction is highest among four case studies. This rather surprising finding may be due to the fact that users appreciate more the existence of an urban square within an urban area that is relatively isolated from its surroundings with coarse-grain destinations scattered within the area. Another explanation may be regarding the strategic location of this square, located right above a densely used metrobus line/stop. This indicates that public spaces like urban squares need to be investigated at multiple scales (e.g., both locally -as individual entities within their physical boundaries- and globally -within their global urban context) and through a combination of both objective and perceived measures. In addition, the underlying reason of users' lower satisfaction levels of Avcılar square as compared to those of Beylikdüzü square might be due to the inadequacy of the usable space within this square, which has the highest density of users/activities among other study areas. Hence, apart from the strategic location of 
urban squares within the urban context, designing flexible and adequate sub-spaces within the urban squares to meet their users' needs is also essential to increase the spatial performance of these public spaces.

\subsection{Limitations and Strengths}

Limitations of this cross-sectional study includes the lack of investigation of the detailed characteristics and physical design features within the squares (e.g., seating elements, public art works), which have been shown to influence user satisfaction and the length of occupation of the space (Gehl, 1987; Project for Public Spaces, 2008; Subiza-Pérez, Vozmediano, \& San Juan, 2020). In addition, actual walking routes of participants to access the squares were not recorded. This would reflect a truer image of actual distances walked to the urban squares. Finally, other types of land-use measures (i.e., land-use mix, number of opening onto each street within square-areas) can capture fully the diversity of urban form within square-areas. Further research can include these variables, which may lead to stronger associations with environmental attributes.

Nevertheless, this study significantly contributes to the methodology applied in POE studies on the analysis of open urban spaces, such as urban squares. This study focused on urban squares located in peripheral districts, which is quite limited in related research. Moreover, the majority of studies investigate urban spaces as singular entities within their physical boundaries, isolated from their urban context. However, user behavior prevalent in an area cannot be described by analyzing the urban area isolated from its global surroundings. This study considered the spatial configuration of urban areas within their urban context, which has both theoretical and practical implications for design of open public spaces. Hence, the comprehensive methodology used in this study can contribute to the methods and criteria for evaluating and studying other urban squares, particularly those located at the periphery.

\section{Conclusion}

This study demonstrates the significance of the use of space syntax analysis to evaluate the built environment surrounding urban squares as a method to examine how the spatial configuration of square-areas is related to user behavior. The findings revealed that both the street network configuration and land-use patterns around a peripheral square are indeed related to its occupation and access. Hence, the focus as well as the findings of this study is directly related to sustainable urban development challenges facing rapidly growing cities such as istanbul. The strength of this research lies in the fact that it focuses specifically on the concept and use of "urban square" designed in areas outside, in vicinity or surrounding of the city center and that it aims to evaluate simultaneously the objective and perceived attributes of the built environment. Findings of this study can contribute significantly to the design and planning of public open spaces specifically in rapidly sprawling metropolitan areas along main transportation axes. Besides theory building, this study has practical implications. Offering a comprehensive methodological approach, this research provides some insights into the design and policy interventions for prospective user-oriented public areas at the periphery. Designing urban squares that are integrated within their surrounding urban context would foster physical activity and social interaction, improving the urban quality of cities and creating sustainable urban forms. This piece of research might lay a base for succeeding in this crucial endeavor.

\section{Acknowledgement}

This research was funded by The Scientific and Technological Research Council of Turkey (TUBITAK), grant number $115 \mathrm{~K} 469$. 


\section{References}

Acar, H., Yavuz, A., Eroğlu, E., Acar, C., Sancar, C., \& Değermenci, A. S. (2020). Analysis of activity, space and user relations in urban squares. Indoor and Built Environment, 1420326X20942271. https://doi.org/10.1177/1420326X20942271

Akad, S., \& Çubukçu, E. (2006). Kentsel Açık Alanlarda Kullanım Sonrası Değerlendirme: İzmir Sahil Bantları Örneği Üzerine Ampirik Bir Araştırma. Planlama Dergisi, (3), 105-115.

Becker, F. D. (1977). Housing messages. John Wiley \& Sons Inc.

Bendjedidi, S., Bada, Y., \& Meziani, R. (2019). Urban plaza design process using space syntax analysis: International Review for Spatial Planning and Sustainable Development, 7(2), 125-142. https://doi.org/10.14246/irspsda.7.2_125

Bin Roslan, M. R., Bin Noor Azman, N. A. H., \& Zakariya, K. (2014). Examining the social and communal values of urban square towards families and youth. UMRAN2014: Fostering Ecosphere In The Built Environment.

Carmona, M. (2010). Public places, urban spaces: the dimensions of urban design (Routledge, Ed.).

Carr, S., Francis, M., Rivlin, L. G., \& Stone, A. M. (1992). Public space. Cambridge University Press.

Churchman, A., \& Ginosar, O. (1999). A theoretical basis for the post-occupancy evaluation of neighborhoods. Journal of Environmental Psychology, 19(3), 267276 https://doi.org/https://doi.org/10.1006/jevp.19 99.0128

Crowe, D., Averbeck, B., Chafee, M., Anderson, J., \& Georgopoulos, A. (2000). Mental Maze Solving. Journal of Cognitive Neuroscience, 12(5), 813-827. https://doi.org/10.1162/089892900562426

Cybriwsky, R. (1999). Changing patterns of urban public space: Observations and assessments from the Tokyo and New York metropolitan areas Cities, 16(4), 223231 https://doi.org/https://doi.org/10.1016/S026 4-2751(99)00021-9

Çakılcıoğlu, M., Reyhan, S., \& Kurt, T. (2010). İstanbul Meydanları: Kent Genelindeki Önemli Meydanların ve Plan Kararları Doğrultusunda Belirlenen Öneri Meydanların Değerlendirilmesi. Istanbul. Retrieved from http://www.skb.gov.tr/wp-content/uploads/2012/09/isTANBUL-MEYDANLARI.pdf

Çalışkan, O. (2005). Doç. Dr. Baykan Günay ile Söyleşi: Şehre biçim verme sanatı ya da düşüncede devrim. Planlama, (3), 6-19.

Dovey, K. ., \& Polakit, K. (2009). Urban slippage: Smooth and striated streetscapes in Bangkok. In Becoming Places: Urbanism / Architecture / Identity / Power (pp. 168-193). Routledge.

El-Geneidy, A., Grimsrud, M., Wasfi, R., Tétreault, P., \& Surprenant-Legault, J. (2014). New evidence on walking distances to transit stops: identifying redundancies and gaps using variable service areas. Transportation, 41(1), 193-210. https://doi.org/10.1007/s11116-013-9508-z

Fard, H. R. (2014). Evaluating spatial behavior in the urban public space of Kadıköy square. 2nd ICAUD International Conference on Architecture and Urban Design, 344-1,344-12. Tirana, Albania.

Francis, M. (2010). Mixed-life places. In T. Banerjee \& A. Loukaitou-Sideris (Eds.), Companion to Urban Design. New York, NY, USA: Routledge.

Frank, L. D., Schmid, T. L., Sallis, J. F., Chapman, J., \& Saelens, B. E. (2005). Linking objectively measured physical activity with objectively measured urban form: findings from SMARTRAQ. American Journal of Preventive Medicine, 28(2 Suppl 2), 117-125. https://doi.org/10.1016/j.amepre.2004.11.001

Garau, C., Annunziata, A., \& Yamu, C. (2020). A walkability assessment tool coupling multi-criteria analysis and space syntax: the case study of Iglesias, Italy. European Planning Studies, 1-23. https://doi.org/10.1080/09654313.2020.1761947

Gehl, J. (1987). Life between buildings: using public space (Island Press, Ed.).

Goličnik, B. (2005). People in place: a configuration of physical form and the dynamic patterns of spatial occupancy in urban open public space. The University of Edinburgh.

Goličnik, B., \& Thompson, C. W. (2010). Emerging relationships between design and use of urban park spaces. Landscape and Urban Planning, 94(1), 38-53.

Gürcan, D. (2002). Spastik çocukların rehabilitasyon ve eğitim mekanlarında programlama ve tasarım kararlarının belirlenmesinde kullanılabilecek bir kullanım sonrası değerlendirme modeli. Selçuk University.

Hepcan, Ş., Kaplan, A., Küçükerbaş, E., \& Özkan, B. (2001). Kemalpaşa (İzmir) Kentsel Dış Mekanlarının Yeterliliği Üzerine Bir Araştırma. Ege Üniversitesi Ziraat Fakültesi Dergisi, 38(2-3), 143-150.

Hermida, M. A., Neira, M., Cabrera-Jara, N., \& Osorio, P. (2017). Resilience in Latin American Cities: Behaviour vs. Space quality in the Riverbanks of the Tomebamba River. Procedia Engineering, 198, 467-481. https://doi.org/https://doi.org/10.1016/j.proeng.2017.07.101

Hillier, B. (1996). Cities as movement economies. Urban Design International, 1(1), 41-60. 
https://doi.org/10.1057/udi.1996.5

Hillier, B., \& Hanson, J. (1984). The social logic of space. Cambridge University Press.

Hillier, B., \& lida, S. (2005). Network effects and psychological effects: a theory of urban movement. 5th International Space Syntax Symposium, 553-564. Delft.

Hillier, B., Penn, A., Hanson, J., Grajewski, T., \& Xu, J. (1993). Natural movement: or, configuration and attraction in urban pedestrian movement. Environment and Planning B: Planning and Design, 20(1), 2966. Retrieved from http://discovery.ucl.ac.uk/1398/3/Hillier1993data_notes.pdf

Jacobs, A. B. (1993). Great Streets. MIT Press.

Jansen-Osmann, P., \& Wiedenbauer, G. (2004). The representation of landmarks and routes in children and adults: A study in a virtual environment. Journal of Environmental Psychology, 24(3), 347-357. https://doi.org/https://doi.org/10.1016/j.jenvp.2004.08.003

Karagenç, O. (2001). Toplu konut alanlarında simgesel performansa yönelik kullanım sonrası değerlendirme modeli. İstanbul Technical University.

Kerr, J., Frank, L., Sallis, J. F., \& Chapman, J. (2007). Urban form correlates of pedestrian travel in youth: differences by gender, race-ethnicity and household attributes. Transportation Research Part D: Transport and Environment, 12(3), 177-182. https://doi.org/10.1016/j.trd.2007.01.006

Kılıç, A. (2001). The Evaluation Of Urban Open Spaces: Kadiköy Square And Its Environment. Istanbul Technical University.

Korkmaz, E. (2001). User's Evaluations Of Urban Open Spaces: Beşiktaş Sample. Istanbul Technical University.

Lee, C., \& Moudon, A. V. (2006). The 3Ds+R: Quantifying land use and urban form correlates of walking. Transportation Research Part D: Transport and Environment, 11(3), 204-215. https://doi.org/10.1016/j.trd.2006.02.003

Lefebvre, H. (1991). The production of space. Oxford: Blackwell Publishing.

Long, J., Rain, D., \& Ratcliffe, M. (2001). Population density vs. urban population: comparative GIS studies in China, India, and the United States. International Union for the Scientific Study of Population Conference, 18-25. Salvador, Brazil.

Lynch, K. (1960). The image of the city. MIT Press.

Lynch, K. (1981). A theory of good city form. Cambridge: MIT Press.

Madanipour, A. (2003). Public and private space of the city. In Public and Private Spaces of the City. Routledge. https://doi.org/10.4324/9780203402856

Malkoc, E., \& Ozkan, M. B. (2010). Post-occupancy Evaluation of a Built Environment: The Case of Konak Square (İzmir, Turkey). Indoor and Built Environment, 19(4), 422-434. https://doi.org/10.1177/1420326X10365819

Marcus, C. C., \& Francis, C. (1998). People places: design guidelines for urban open space. New York.

Marcus, L., \& Colding, J. (2014). Toward an integrated theory of spatial morphology and resilient urban systems. Ecology and Society, 19(4). Retrieved from http://www.jstor.org/stable/26269695

Marušić, B. G. (2011). Analysis of patterns of spatial occupancy in urban open space using behaviour maps and GIS. Urban Design International, 16(1), 36-50.

Marušić, B. G., \& Marušić, D. (2012). Behavioural Maps and GIS in Place Evaluation and Design. In D. M. E.-B. M. Alam (Ed.), Application of Geographic information System (pp. 113-138). Rijeka: IntechOpen. https://doi.org/10.5772/47940

Monokrousou, K., \& Giannopoulou, M. (2016). Interpreting and Predicting Pedestrian Movement in Public Space through Space Syntax Analysis. Procedia - Social and Behavioral Sciences, 223, 509-514. https://doi.org/https://doi.org/10.1016/j.sbspro.2016.05.312

Montgomery, J. (1998). Making a city: urbanity, vitality and urban design. Journal of Urban Design, 3(1), 93116.

Peponis, J. (2001). Interacting questions and descriptions: How do they look from here? Proceedings of the 3rd International Space Syntax Symposium. Atlanta, Georgia.

Preiser, W. F. E. (1994). Built environment evaluation: conceptual basis, benefits and uses. Journal of Architectural and Planning Research, 11(2), 91-107. Retrieved from http://www.jstor.org/stable/43029114

Preiser, W. F. E. (2001). Feedback, feedforward and control: post-occupancy evaluation to the rescue. Building Research \& Information, 29(6), 456-459. https://doi.org/10.1080/09613210110072692

Project for Public Spaces. (2008). A Primer on Seating. Retrieved from https://www.pps.org/article/general seating

Rabinowitz, H. Z. (1975). Buildings in use study. Center for Architecture and Urban Planning Research Books. Ramírez-Lovering, D. (2008). Opportunistic urbanism. RMIT University Press. 
Reilly, M., \& Landis, J. (2002). The influence of built-form and land use on mode choice. Washington, DC.

Riazi, N. A., \& Faulkner, G. (2018). Children's Independent Mobility. In Children's Active Transportation (pp. 77-91). Elsevier. https://doi.org/10.1016/B978-0-12-811931-0.00005-3

Sanoff, H. (1994). School design. New York, NY, USA: John Wiley \& Sons Inc.

Schwebel, D. C., Wu, Y., Swanson, M., Cheng, P., Ning, P., Cheng, X., Hu, G. (2018). Child pedestrian streetcrossing behaviors outside a primary school: Developing observational methodologies and data from a case study in Changsha, China. Journal of Transport \& Health, 8, 283-288. https://doi.org/https://doi.org/10.1016/j.jth.2018.01.005

Sherman, S. A., Varni, J. W., Ulrich, R. S., \& Malcarne, V. L. (2005). Post-occupancy evaluation of healing gardens in a pediatric cancer center. Landscape and Urban Planning, 73(2), 167-183. https://doi.org/https://doi.org/10.1016/j.landurbplan.2004.11.013

Subiza-Pérez, M., Vozmediano, L., \& San Juan, C. (2020). Welcome to your plaza: Assessing the restorative potential of urban squares through survey and objective evaluation methods. Cities, 100, 102461. https://doi.org/https://doi.org/10.1016/j.cities.2019.102461

Tonkiss, F. (2005). Space, the city and social theory: Social relations and urban Forms. Cambridge: Polity Press. Turner, A. (2001). Angular Analysis. Proceedings of the 3rd International Symposium on Space Syntax Georgia Institute of Technology. Retrieved from http://discovery.ucl.ac.uk/35952/

Varoudis, T. (2014). Depthmap X (Computer Program). London, United Kingdom.

Whitehouse, S., Varni, J. W., Seid, M., Cooper-Marcus, C., Ensberg, M. J., Jacobs, J. R., \& Mehlenbeck, R. S. (2001). Evaluating a children's hospital garden environment: Utilization and consumer satisfaction. Journal of Environmental Psychology, 21(3), 301314 https://doi.org/https://doi.org/10.1006/jevp.20 01.0224

Whyte, W. H. (1980). The social life of small urban spaces. Washington, D.C.

\section{Resume}

Ayse Ozbil is an Associate Professor at the Department of Architecture and Built Environment, Northumbria University. Her research interests mainly lie in the fields of spatial modeling and urban form analysis using space syntax techniques. Her work is directed towards pedestrian-friendly neighborhood and street design strategies enhancing active transportation in cities. Her recent studies have focused on walkability and obesity, transit-oriented planning, post occupancy evaluation and design of sustainable cities. Dr. Ozbil has been a member of the editorial board of Urban Design International since 2012, and her work has been published in numerous peer-reviewed journals.

Demet Yesiltepe is an urban planner and designer, and currently a PhD student in Architecture and Built Environment at Northumbria University. Her PhD research contributes to the understanding of how spatial layouts, particularly the presence of landmarks, affect people's navigational performances and what factors make it easier or more challenging for people to find their way. Her research interests include geographic information systems (GIS), Space Syntax, spatial analysis, walkability, urban form modelling and urban design.

Sertac Erten leads Masterplanning and Urban Design Services at Arup-Turkey. She has a professional and academic background of more than 20 years. A city planner by training with MsC and PhD degrees in urban design in Middle East Technical University, she brings an expert for integrated complex systems in built environment at Arup while she lectures in several universities in architectural departments in Istanbul. Sertac has a broad experience of planning / urban design consultancies for local governments of Turkish cities. She participated and leaded several award-winning urban design competitions in Turkey. Her focus areas are urban design competitions, neighbourhood and street-scale projects, large-scale masterplanning, ArcGIS in urban design scale, localization of UN Sustainable Development Goals (UNSDGs) in masterplans, design and masterplanning of Science and Technology Parks (STPS).

Özlem Özer is a city planner specializing in spatial analysis of road networks, strategic planning and GIS technologies. She received her PhD in Urban and Regional Planning in 2014. She worked as an urban planner in national and international planning projects for 8 years before becoming an academic. After spending one year as a guest lecturer in Environmental Planning and Design graduate program in University of Georgia in 2010, she has started to work as an academic in Architecture and Urban Design departments in Turkey. She is currently working as a lecturer at the Architecture Department of Istanbul Gelişim University. Her research interests focus on the spatial analysis of the urban environment and the effects of spatial relationships on user behavior. 
Tuğçe Gürleyen graduated from the Middle East Technical University, Department of City and Regional Planning in 2015. She received her master's degree from Istanbul Technical University, City Planning Program by her thesis named "Spatial narrative of memory trajectories in urban amnesia: An etnographic view of everyday life of Bomonti" in 2018. She is still on her PhD studies in the City and Regional Planning of Istanbul Technical University. She worked as a project assistant at Özyeğin University from 2015 to 2018. She worked as an urban designer at EnsPd Project Development in 2017. Between 2017 and 2019, she worked as an instructor at Medipol University. She gave various courses in the Department of Urban Design and Landscape Architecture and Department of Architecture. She still continues her professional career at Arup where she started working as an urban planner in 2019. Her research areas focus on temporary urbanism, participatory urban design, urban sociology, community engagement, pedestrian mobility, streetscape, place-memory relations, mapping and visualization.

Ezgi Zünbüloğlu graduated from ITU as an urban planner in 2015 and she received an acceptance from Urban Design M.Sc. in the same year. During the master's degree she participated in various research projects. Due to her interest in symbols in urban space and their effects on users and perception of urban space, she completed her master's thesis with the study "Semantics, Perception and Graffiti in Urban Space". Lastly, within the scope of the project carried out with the Istanbul Metropolitan Municipality, she took part in the team established to digitize the land use plans and implementary development plans in order to create a 3D database, extracting plan notes, and determining and organizing the connection of lower and upper scale plans. 